\title{
Phosphohexosyl Recognition is a General Characteristic of Pinocytosis of Lysosomal Glycosidases by Human Fibroblasts
}

\author{
Arnold Kaplan, David Fischer, Daniel achord, and William Sly, \\ Departments of Medicine and Pediatrics, Washington University School \\ of Medicine, Division of Medical Genetics, St. Louis Children's Hospital, \\ St. Louis, Missouri 63110
}

A B S T RACT We recently presented data showing that mannose-6-phosphate was a potent competitive inhibitor of pinocytosis of human platelet $\beta$-glucuronidase, and that treatment of "high-uptake" forms of the enzyme with alkaline phosphatase destroyed the high-uptake property of the enzyme without diminishing its catalytic activity. These data indicate that phosphate is a necessary component of the recognition marker on the enzyme for pinocytosis by human fibroblasts, and suggest that the phosphate on highuptake forms of the enzyme is present as a phosphohexosyl moiety. Results presented here show that mannose-6-phosphate is also a potent inhibitor of pinocytosis of the following enzyme preparations: (a) $\beta$-glucuronidase from human spleen, liver, placenta, and urine; $(b) \beta$-hexosaminidase and $\beta$-galactosidase from human platelets; (c) $\beta$-hexosaminidase from human fibroblast secretions. Alkaline phosphatase treatment of all of these enzymes except $\beta$-galactosidase, which was unstable to the incubation conditions and could not be tested, greatly diminished the uptake activity of the enzymes without diminishing their catalytic activity. These results suggest that phosphohexosyl recognition is a general characteristic of pinocytosis of lysosomal glycosidases.

\section{INTRODUCTION}

Uptake of lysosomal enzymes by fibroblasts, originally recognized as uptake of corrective factors by enzyme-

This work was presented in abstract form. 1977. Clin. Res. 25: 471A. (Abstr.).

Dr. Kaplan's present address is Department of Microbiology, St. Louis University School of Medicine, St. Louis Mo. 63104. Reprint requests should be addressed to Dr. Sly.

Received for publication 24 May 1977 and in revised form 13 July 1977. deficient fibroblasts (1), displays the selectivity and saturability expected for a receptor-mediated process (2). Selectivity for $\beta$-glucuronidase uptake was evident from the fact that only certain relatively acidic forms of the enzyme, called "high-uptake" forms, were taken up at rates that greatly exceeded the rate of nonspecific, fluid- or bulk-phase endocytosis (3-6). Saturability has been demonstrated with several high-uptake enzymes (6-9). We recently reported evidence that high-uptake $\beta$-glucuronidase from human platelets is a phosphoglycoprotein, and that phosphohexose is an essential component of the recognition marker on the enzyme for the fibroblast pinocytosis receptor (6).

The phosphohexose on the enzyme has not yet been demonstrated directly. The evidence that phosphate is present on the enzyme and is essential for uptake by fibroblasts was provided by the discovery that alkaline phosphatase treatment of high-uptake enzyme destroyed its uptake activity without diminishing its catalytic activity. This treatment also converted the enzyme to less acidic forms. The suggestion that a phosphate monoester on the high-uptake enzyme is linked to a D-mannose-type sugar was based on the finding that D-mannose-6-phosphate was a potent competitive inhibitor of $\beta$-glucuronidase pinocytosis, in fact, a 1,000-fold more potent inhibitor than D-mannose. In addition, phosphomannose-containing yeast mannans were also potent competitive inhibitors of $\beta$ glucuronidase pinocytosis.

Here we present evidence that phosphohexosyl recognition is not limited to pinocytosis of $\beta$-glucuronidase from platelets. Phosphohexosyl recognition is shown to be involved in pinocytosis of $\beta$-glucuronidase from four other tissue sources, in pinocytosis of $\beta$-galactosidase and $\beta$-hexosaminidase from platelet extracts, and in pinocytosis of $\beta$-hexosaminidase from fibroblast secretions. Thus, we suggest that phosphohexosyl 
recognition is a general property of pinocytosis of lysosomal glycosidases and that phosphohexose is an essential part of the common recognition marker (10) on high-uptake lysosomal enzymes.

\section{METHODS}

Materials. Most reagents were purchased from Sigma Chemical Co., St. Louis, Mo. Homogenous Escherichia coli alkaline phosphatase was a gift of Dr. Milton Schlesinger, Washington University, St. Louis, Mo. Blood platelets were a gift of the American National Red Cross Blood Bank, St. Louis, Mo. Normal human liver, spleen, and placenta were obtained from the Departments of Pathology and Obstetrics, Washington University School of Medicine, St. Louis, Mo. Cultured fibroblasts were established from skin biopsies obtained from patient J. E. with $\beta$-glucuronidase deficiency mucopolysaccharidosis (available as cell strain GM 151 from the Human Mutant Cell Repository, Camden, N.J.), from patient E. W. with Sandoff's disease (Montreal Tissue Repository, Department of Pediatrics, McGill University, Montreal, Canada), patient T. M. with I-cell disease (Division of Medical Genetics, University of Texas Health Science Center, Dallas, Tex.), and from a normal control.

Enzyme preparations. A fraction rich in high-uptake $\beta$ glucuronidase was partially purified from platelets by antibody-Sepharose immunoadsorption, followed by chromatography on DEAE-Sephadex as described (6). This $\beta$ glucuronidase preparation had a specific activity of $3 \times 10^{5}$ $\mathrm{U} / \mathrm{mg}$ protein.

$\beta$-Glucuronidase from urine and from Polytron homogenates (Polytron, Brinkmann Instruments Inc., Westburg, N.Y.) of other organs was prepared by immunoadsorbant chromatography as described $(3,4)$. However, the extracts were buffered in $0.05 \mathrm{M}$ EDTA, pH 8.0, instead of Tris$\mathrm{HCl}$, and human serum albumin was added to $0.2 \mathrm{mg} / \mathrm{ml}$ final concentration to the urea eluates from the immunoadsorbent columns before concentration and exhaustive dialysis.

$\beta$-Hexosaminidase was partially purified from platelet extracts with the glycoprotein fraction previously described as " $\beta$-glucuronidase-free human platelet glycoproteins" (6). After $\beta$-glucuronidase was removed from the platelet extract by immunoadsorbent chromatography (6) the remaining glycoproteins were isolated by adsorption to concanavalin ASepharose and elution with $\alpha$-methylmannoside. $2 \mathrm{mg}$ of protein containing $3 \times 10^{5} \mathrm{U} / \mathrm{mg} \beta$-hexosaminidase and $<10 \mathrm{U} / \mathrm{mg}$ $\beta$-glucuronidase were obtained from the platelets from $200 \mathrm{U}$ of outdated platelet concentrate, (1 liter of $1 \%$ deoxycholate platelet lysate) (3).

Fibroblast secretion $\beta$-hexosaminidase was purified from normal human fibroblast secretions. Fibroblasts were split 1:5 into Corning roller bottles $\left(490 \mathrm{~cm}^{2}\right)$ Corning Glass Works, Science Products Div., Corning, N.Y. and grown for 1 wh in Eagle's minimal essential medium (Grand Island Biological Co., Grand Island, N.Y.) containing $15 \%$ heatinactivated fetal calf serum, $1 \mathrm{mM}$ sodium pyruvate, $100 \mathrm{U} / \mathrm{ml}$ penicillin, and $100 \mu \mathrm{g} / \mathrm{ml}$ streptomycin sulfate. Then cells were washed with saline and maintained in serum-free Waymouth media (Grand Island Biological Co.) containing $2 \mathrm{mg} /$ $\mathrm{ml}$ hexosaminidase-free human serum albumin. Media was changed every 6 days. The $\beta$-hexosaminidase-containing medium $(800-1,200 \mathrm{U} / \mathrm{ml})$ was concentrated by ultrafiltration, dialyzed against $0.05 \mathrm{M}$ sodium citrate, $\mathrm{pH} 4.5$, and applied to an affinity resin ( $p$-aminophenyl- $N$-acetyl- $\beta$-D-thioglucosamine-Sepharose) (11). The $\beta$-hexosaminidase was eluted with the citrate buffer containing $0.1 \mathrm{MN}$-acetylglucosamine and $0.1 \mathrm{mg} / \mathrm{ml}$ human serum albumin, concentrated by ultra- filtration, and dialyzed against $0.01 \mathrm{M}$ Tris- $\mathrm{HCl}, \mathrm{pH} 7.6,0.075$ $\mathrm{M} \mathrm{NaCl}$.

$\beta$-Galactosidase was prepared from platelet lysates (6) by affinity chromatography on Sepharose 4B-amino-hexyl-1-thio$\beta$-D-galactopyranoside as described by Miller et al. (12), except that the enzyme was applied and eluted in $0.01 \mathrm{M}$ sodium acetate, $\mathrm{pH} 4.4$.

Assays. Fluorometric enzyme assays measured release of 4-methyl-umbelliferone from the appropriate glycoside (13). Synthetic substrate concentrations were $10 \mathrm{mM}$ in $0.1 \mathrm{M}$ sodium acetate, $\mathrm{pH} 4.8$, for $\beta$-glucuronidase, $5 \mathrm{mM}$ in $0.02 \mathrm{M}$ sodium phosphate-citrate, $\mathrm{pH} 4.4$, for $\beta$-hexos-aminidase; and

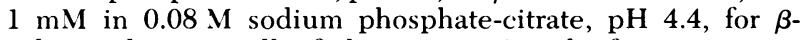
galactosidase. In all of the assays, $25 \mu \mathrm{l}$ of enzyme was added to $100 \mu \mathrm{l}$ of substrate and then the mixture was incubated at $37^{\circ} \mathrm{C}$. Reactions were stopped by the addition of $1.8 \mathrm{ml}$ of glycine-carbonate buffer, pH 10.3 (13). $1 \mathrm{U}$ of activity is the amount of enzyme which catalyzes the release of $1 \mathrm{nmol}$ of 4-methylumbelliferone/hr. Protein was measured according to Lowry et al. (14). Pinocytosis of enzymes by fibroblasts was measured as previously described (6). The conditions for pinocytosis rate measurements are given in the legend to Table $\mathbf{I}$.

\section{RESULTS}

We previously reported different rates of pinocytosis by human fibroblasts for $\beta$-glucuronidase prepared from different human tissue sources (3). The pinocytosis rate correlated with the relative amount of acidic high-uptake forms in the enzyme preparations (4). Table I compares the pinocytosis of human $\beta$ -

TABLE I

Effect of Mannose-6-Phosphate on the Rate of Pinocytosis of $\beta$-Glucuronidase from Different Human Tissues

\begin{tabular}{|c|c|c|c|c|}
\hline \multicolumn{2}{|c|}{ Added $\beta$-glucuronidase } & \multicolumn{2}{|c|}{$\begin{array}{c}\text { Pinocytosis of } \\
\beta \text {-glucuronidase }\end{array}$} & \multirow[b]{2}{*}{$\begin{array}{l}\text { Int.1. } \\
\text { bitiol }\end{array}$} \\
\hline \multirow[t]{2}{*}{$\begin{array}{l}\text { Tissue } \\
\text { source }\end{array}$} & $\begin{array}{l}\text { Concen- } \\
\text { tration }\end{array}$ & $\begin{array}{c}\text { No } \\
\text { additions }\end{array}$ & $\begin{array}{l}\text { D-Mannose- } \\
\text { 6-Phosphate } \\
\text { added (1 mM) }\end{array}$ & \\
\hline & $U / m l$ & $U / m g / h$ & $U / m g / h$ & $\%$ \\
\hline Platelets & 10,800 & 248 & 23.0 & 91 \\
\hline Spleen & 6,060 & 101 & 7.8 & 92 \\
\hline Liver & 7,000 & 33 & 2.9 & 91 \\
\hline Placenta & 6,860 & 28 & 0.7 & 98 \\
\hline Urine & 6,526 & 16 & 2.6 & 84 \\
\hline
\end{tabular}

* Pinocytosis of $\beta$-glucuronidase from different tissues by fibroblasts was measured in confluent $35-\mathrm{mm}$ dishes containing $\cong 0.2 \mathrm{mg}$ cell protein/dish. $\beta$-Glucuronidase-deficient fibroblasts were exposed to enzyme in $1.0 \mathrm{ml}$ of serum containing medium for $2 \mathrm{~h}$ at $37^{\circ} \mathrm{C}$, after which cell protein and cell-associated enzyme were determined as described previously (6). Activity associated with cells after $5 \mathrm{~s}$ at $0^{\circ} \mathrm{C}$ was subtracted from these values. Pinocytosis rates represent the mean of duplicate measurements. The mean deviation of duplicates was $\pm 4 \%$. The rate of nonspecific fluid endocytosis estimated from the rate of $\left[\right.$ methox $\left.y-{ }^{3} \mathrm{H}\right]$ dextran uptake was $0.15 \mu \mathrm{l} / \mathrm{mg}$ per $\mathrm{h}$. 
glucuronidase from different sources and the effect of mannose-6-phosphate on the pinocytosis rate. Platelet and spleen enzyme are much richer in high-uptake forms than enzyme from liver, placenta, or urine, as previously reported (3-6). However, even the enzyme with the lowest pinocytosis rate (urinary enzyme) is taken up in the absence of mannose-6-phosphate at a rate that is one to two orders of magnitude greater than the rate of nonspecific fluid endocytosis. The most important point from Table I is that despite differences in the amount of high-uptake enzyme in $\beta$-glucuronidase from different sources, mannose-6-phosphate dramatically inhibits the pinocytosis of the enzyme from every source tested.

We also reported previously (6) that the pinocytosis of human platelet $\beta$-glucuronidase was greatly diminished by alkaline phosphatase treatment of the enzyme. Table II presents an experiment confirming this result and shows, in addition, that inclusion of $1 \mathrm{mM}$ inorganic phosphate during the treatment with phosphatase completely inhibits the phosphatase effect on the

TABLE II

Effect of Prior Alkaline Phosphatase Treatment on the Rate of Pinocytosis of $\beta$-Glucuronidase from Different Tissue Sources

\begin{tabular}{llcc}
\hline $\begin{array}{c}\text { Tissuc } \\
\text { source } \\
\text { of } \beta \text {-gluc- } \\
\text { uronidase }\end{array}$ & \multicolumn{1}{c}{$\begin{array}{c}\text { Addition to first } \\
\text { incubation* }\end{array}$} & $\begin{array}{c}\text { Pino- } \\
\text { cytosis } \\
\text { of } \beta \text {-gluc- } \\
\text { uronidase }\end{array}$ & $\begin{array}{c}\text { Inactivation } \\
\text { of uptake } \\
\text { activity }\end{array}$ \\
\hline \multirow{5}{*}{ Platelet } & None & 230 & - \\
& Alkaline phosphatase & 44 & 81 \\
& Pi (1 mM) & 234 & 0 \\
& Pi plus alkaline phospha- & 243 & 0 \\
& tase & 138 & - \\
Spleen & None & 32 & 77 \\
& Alkaline phosphatase & 33 & - \\
Liver & None & 10 & 70 \\
& Alkaline phosphatase & 29 & - \\
Placenta & None & 13 & 55 \\
& Alkaline phosphatase & 15 & - \\
Urine & None & 2 & 87 \\
& Alkaline phosphatase & & \\
\hline
\end{tabular}

* $\beta$-Glucuronidase preparations from the tissue sources listed in Table I were incubated first in a final volume of $0.1 \mathrm{ml}$ of $0.028 \mathrm{M}$ Tris $\mathrm{HCl}, \mathrm{pH} 8.0,0.075 \mathrm{M} \mathrm{NaCl}$ with or without addition of $80 \mu \mathrm{g} / \mathrm{ml}$ of alkaline phosphatase for $4 \mathrm{~h}$ at $37^{\circ} \mathrm{C}$. Samples were diluted to $2.0 \mathrm{ml}$ with serum-containing medium to give the enzyme concentrations indicated in Table $I$, and the pinocytosis rates for these $\beta$-glucuronidase preparations were measured as described in Methods. The specific activity of the alkaline phosphatase was $25 \mu \mathrm{M} / \mathrm{mg}$ per min Pi release.
TABLE III

Effect of Mannose-6-Phosphate on the Rate of Pinocytosis of Different Lysosomal Glycosidases

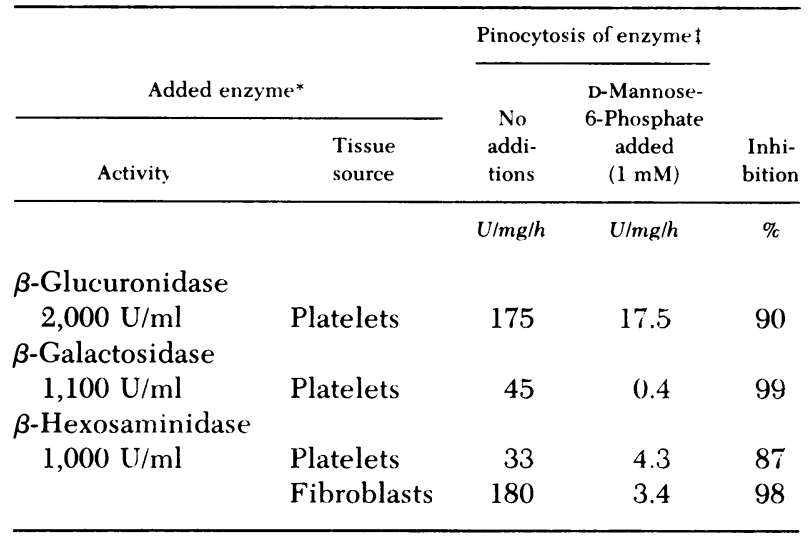

* Enzyme from platelets and fibroblast secretions were prepared as described in Methods.

$\downarrow$ Pinocytosis was measured as in Tables I and II with $\beta$-glucuronidase-deficient fibroblasts as acceptor cells for $\beta$-glucuronidase, Sandhoff's disease fibroblasts for $\beta$ hexosaminidase, and I-cell disease fibroblasts for $\beta$-galactosidase.

platelet enzyme. Evidence that the alkaline phosphatase treatment of platelet $\beta$-glucuronidase reduces the amount of cell-associated enzyme by destroying the uptake property, rather than rendering the enzyme more sensitive to inactivation following uptake, was provided by the following experiment. When $2,000 \mathrm{U}$ of either untreated or alkaline phosphatase-treated platelet $\beta$-glucuronidase was incubated with cells for $15 \mathrm{~h}$, over $98 \%$ of the added $\beta$-glucuronidase activity was recovered as the sum of the cell-associated activity plus that remaining in the medium, even though $28 \%$ of the untreated enzyme and only $4.8 \%$ of the alkaline phosphatase-treated enzyme had been taken up. Thus, the alkaline phosphatase-treated enzyme that did not appear in the cells was still present in the medium. The data in Table II on $\beta$ glucuronidase from other sources indicate that alkaline phosphatase treatment also greatly reduces the susceptibility to pinocytosis (destroys the high-uptake property) of $\beta$-glucuronidase from spleen, liver, placenta, and urine. Thus, $\beta$-glucuronidase from these sources appears to have a similar recognition marker to that of enzyme from platelets.

We next compared the effect of mannose-6-phosphate and other hexose phosphates on pinocytosis of other lysosomal hydrolases to their effect on platelet $\beta$-glucuronidase. Table III presents data on the inhibition of pinocytosis of several lysosomal hydrolases by mannose-6-phosphate. The striking inhibition of enzyme pinocytosis by mannose-6-phosphate is evident, not only for $\beta$-glucuronidase from platelets as previ- 
ously reported (6), but also for $\beta$-galactosidase and $\beta$-hexosaminidase from platelet extracts, and for $\beta$ hexosaminidase from fibroblast secretions. Fig. 1 summarizes data comparing several hexose phosphates as inhibitors of pinocytosis of four different hydrolase preparations. In every case, mannose-6-phosphate was the most potent inhibitor of enzyme pinocytosis. The patterns of inhibition of pinocytosis were similar to each other and similar to that previously reported for platelet $\beta$-glucuronidase (6).

Table IV demonstrates the sensitivity of the highuptake property of $\beta$-hexosaminidase to prior treatment of the enzyme with alkaline phosphatase. Although

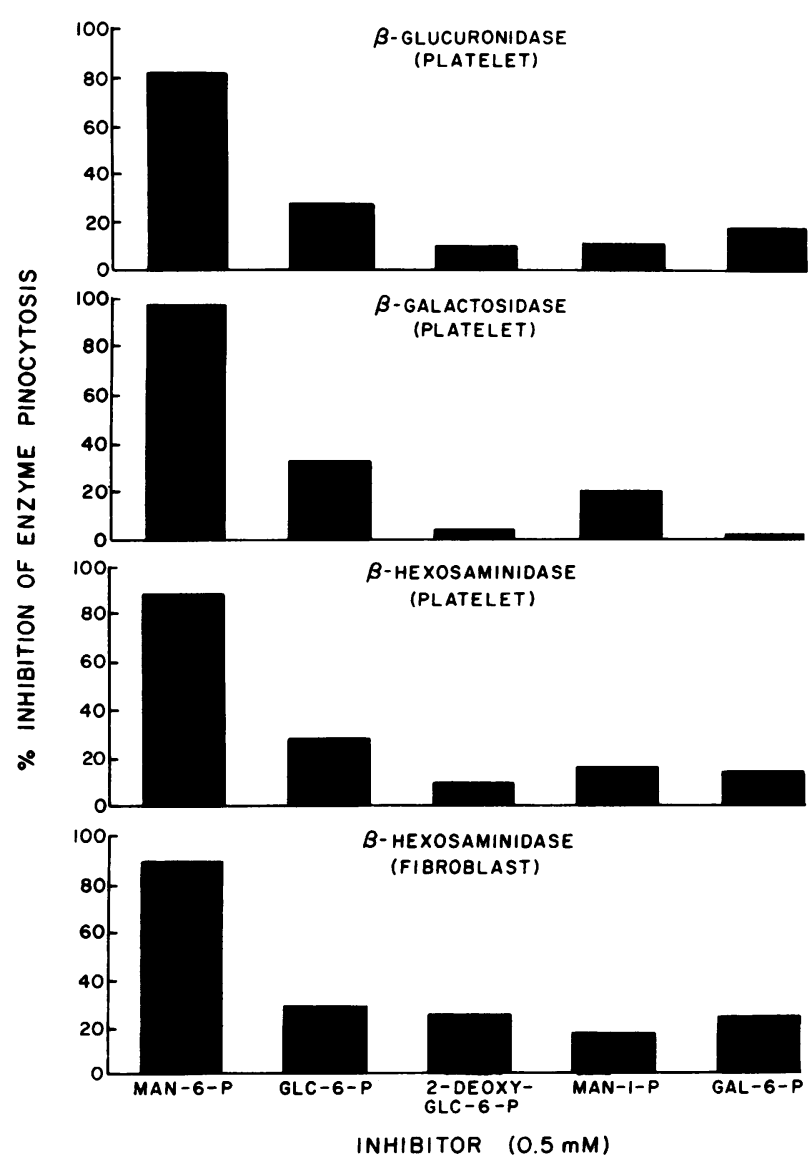

FIGURE 1 Inhibition of enzyme pinocytosis by different sugar phosphates. The enzymes were prepared as described in Methods. Pinocytosis was measured as in Tables I and II in the presence and absence of the indicated hexose phosphates. $\beta$-Glucuronidase-deficient fibroblasts were used as acceptor cells for $\beta$-glucuronidase, Sandhoff's disease fibroblasts for $\beta$-hexosaminidase, and I-cell disease fibroblasts for $\beta$-galactosidase. The enzyme concentration used and the pinocytosis rate for each enzyme in the absence of inhibitors were: $\beta$-glucuronidase (platelet) $2,000 \mathrm{U} / \mathrm{ml}, 162 \mathrm{U} / \mathrm{mg}$ per h; $\beta$-galactosidase (platelet) $3,600 \mathrm{U} / \mathrm{ml}, 58 \mathrm{U} / \mathrm{mg}$ per $\mathrm{h} ; \boldsymbol{\beta}$ hexosaminidase (platelet) $10,000 \mathrm{U} / \mathrm{ml}, 69 \mathrm{U} / \mathrm{mg}$ per $\mathrm{h}$; and $\beta$-hexosaminidase (fibroblast) $1,400 \mathrm{U} / \mathrm{ml}, 162 \mathrm{U} / \mathrm{mg}$ per $\mathrm{h}$.
TABLE IV

Effect of Prior Alkaline Phosphatase Treatment on the Rate of Pinocytosis of $\beta$-Hexosaminidase from Human Platelets and Human Fibroblast Medium

\begin{tabular}{clcc}
\hline $\begin{array}{c}\text { Tissue source } \\
\text { of } \beta \text {-hexos- } \\
\text { aminidase* }\end{array}$ & \multicolumn{1}{c}{$\begin{array}{c}\text { Additions to first } \\
\text { incubation }\end{array}$} & $\begin{array}{c}\text { Pinocytosis } \\
\text { of } \beta \text {-hexos- } \\
\text { aminidase } \$\end{array}$ & $\begin{array}{c}\text { Inacti- } \\
\text { vation of } \\
\text { uptake } \\
\text { activity }\end{array}$ \\
\hline & Ulmg/h & $\%$ \\
Platelets & None & 166 & - \\
$(5,000 \mathrm{U} / \mathrm{ml})$ & Alkaline phosphatase & 31 & 81 \\
& Pi (1 mM) & 184 & 0 \\
& Pi plus alkaline & 188 & 0 \\
Fibroblasts & None & 195 & - \\
$(1,000 \mathrm{U} / \mathrm{ml})$ & Alkaline phosphatase & 4 & 98 \\
\hline
\end{tabular}

* $\beta$-Hexosaminidase from human blood platelets and from fibroblast secretions were prepared as described in Methods. $\$$ Treatment of $\beta$-hexosaminidase during the first incubation was as described for $\beta$-glucuronidase in Table II except that incubations of fibroblast secretion enzymes were carried out in dialysis bags immersed in $300 \mathrm{vol}$ of $0.028 \mathrm{M}$ Tris $\mathrm{HCl}$, pH 8.0, 0.075 M NaCl.

$\S$ The pinocytosis rate for $\beta$-hexosaminidase was measured in Sandhoff's disease fibroblasts as described in Methods.

catalytic activity was not affected by this treatment, the susceptibility of the enzyme to pinocytosis was greatly diminished. As was the case for $\beta$-glucuronidase (Table II), inclusion of $1 \mathrm{mM}$ inorganic phosphate during the phosphatase treatment completely inhibited the phosphatase effect on the high-uptake platelet enzyme. Note that the $\beta$-hexosaminidase from fibroblast secretions is richer in high-uptake enzyme than platelet $\beta$-hexosaminidase, as judged by the fraction of added enzyme internalized in the short incubation, but its high-uptake property is completely destroyed by treatment of the enzyme with alkaline phosphatase.

The effect of alkaline phosphatase treatment on the high-uptake property of $\beta$-galactosidase from platelets could not be examined because $\beta$-galactosidase, unlike $\beta$-glucuronidase, and $\beta$-hexosaminidase, was unstable to the alkaline incubation conditions used for the phosphatase treatment. Its catalytic activity was rapidly lost under these conditions, whether or not alkaline phosphatase was added.

\section{DISCUSSION}

The evidence presented here supports the generality of phosphohexosyl recognition in the pinocytosis of lysosomal glycosidases. Since pinocytosis of $\beta$ glucuronidase from all human sources examined is inhibited by mannose-6-phosphate and diminished by prior treatment of the enzyme with alkaline phospha- 
tase, the phosphohexosyl recognition component on $\beta$-glucuronidase is clearly not restricted to $\beta$-glucuronidase from platelets. Furthermore, the findings with $\beta$-galactosidase and $\beta$-hexosaminidase from platelets indicate that this type of recognition component is present on other platelet hydrolases. A further case for generality is provided by the studies on $\beta$-hexosaminidase from fibroblast secretions. Without these data one could not exclude the possibility that the phosphohexosyl recognition component is limited to blood platelet enzymes. Small amounts of high-uptake enzymes in other organs could be due to the presence of blood platelets in these organs. However, the high-uptake fibroblast secretion enzyme cannot be attributed to blood platelets. High-uptake enzyme was found to be a substantial fraction of the $\beta$ hexosaminidase secreted by cultured fibroblasts for at least $4 \mathrm{wk}$ after transfer from serum-containing to serum-free medium. ${ }^{1}$ The high-uptake $\beta$-hexosaminidase from fibroblast secretions had the same properties as high-uptake $\beta$-hexosaminidase from platelets and as high-uptake $\beta$-glucuronidase from all sources tested. Additionally, although the data have not yet been published, Neufeld et al. (9) recently reported that high-uptake human $\alpha$-L-iduronidase from urine was similar to human platelet $\beta$-glucuronidase (6) in the sensitivity of its uptake to inhibition by mannose6-phosphate, and in the susceptibility of its uptake activity to inactivation by alkaline phosphatase.

Hickman and Neufeld (10) originally proposed that lysosomal enzymes have a "common recognition marker" for uptake and suggested that this recognition marker was defective or masked on lysosomal enzymes from I-cell disease fibroblasts. Carbohydrate in the recognition marker was suggested by the finding that the uptake activity of $\beta$-hexosaminidase was inactivated by treatment of the enzyme with periodate (15). Hieber et al. (7) recently suggested glycosidically bound mannose in the recognition marker on $\beta$ galactosidase from beef testes, but concluded that uptake of this enzyme was mediated by a different system than that responsible for $\beta$-glucuronidase uptake. Our recent studies (6) implicated phosphate in the recognition marker on high-uptake human platelet $\beta$-glucuronidase and suggested that the phosphate was present as a phosphomannosyl moiety on the enzyme. The present report supports the generality of a phosphohexose-type recognition marker on human lysosomal enzymes and suggests that phosphomannose is an essential part of the previously suggested common recognition marker.

The findings implicating phosphohexose on lysosomal enzymes were unexpected. Until recently no

${ }^{1}$ Grubb, J. and W. Sly. Unpublished observations, precedent could be cited for phosphomannosyl-containing glycoproteins from mammalian sources, though yeast mannans provided clear examples (16). However, Davis et al. $(17,18)$ recently reported phosphatecontaining glycoproteins in rat brain and found phosphomannosyl residues in the glycopeptides isolated from these glycoproteins.

\section{ACKNOWLEDGMENTS}

We thank Mr. John Hinton for expert technical assistance; Mr. Alfonso Gonzalez-Noriega for help with several enzyme preparations; Dr. F. E. Brot for preparing urinary $\beta$ glucuronidase and for the antibody-Sepharose used to purify $\beta$-glucuronidase; Dr. Tom Doebber for the affinity adsorbent for $\beta$-hexosaminidase; and Dr. Milton Schlesinger for homogeneous alkaline phosphatase from $E$. coli. This research was supported by National Institute of General Medical Sciences grant GM 21096 and by the Ranken Jordan Trust Fund for Crippling Diseases in Children.

\section{REFERENCES}

1. Neufeld, E. F., and M. J. Cantz. 1971. Corrective factors for inborn errors of mucopolysaccharide metabolism. Ann. N. Y. Acad. Sci. 179: 580-587.

2. Neufeld, E. F., T. W. Lim, and L. J. Shapiro. 1975. Inherited disorders of lysosomal metabolism. Annu. Rev. Biochem. 44: 357-375.

3. Brot, F. E., J. H. Glaser, K. J. Roozen, W. S. Sly, and P. D. Stahl. 1974. In vitro correction of deficient human fibroblasts by $\beta$-glucuronidase from different human sources. Biochem. Biophys. Res. Commun. 57: $1-8$.

4. Glaser, J. H., K. J. Roozen, F. E. Brot, and W. S. Sly. 1975. Multiple isoelectric and recognition forms of human $\beta$-glucuronidase activity. Arch. Biochem. Biophys. 166: 536-542.

5. Lagunoff, D., D. M. Nicol, and P. Pritzl. 1973. Uptake of $\beta$-glucuronidase by deficient human fibroblasts. Lab. Invest. 29: 449-453.

6. Kaplan, A., D. T. Achord, and W. S. Sly. 1977. Phosphohexosyl receptors on human fibroblasts. Proc. Natl. Acad. Sci. U.S.A. 74: 2026-2030.

7. Hieber, V., J. Distler, R. Myerowitz, R. D. Schmickel, and G. W. Jourdian. 1976. The role of glycosidically bound mannose in the assimilation of $\beta$-galactosidase by generalized gangliosidosis fibroblasts. Biochem. Biophys. Res. Commun. 73: 710-717.

8. Von Figura, K., and H. Kresse. 1973. Quantitative aspects of pinocytosis and intracellular fate of $\mathrm{N}$-acetyl$\alpha$-D-glucosaminidase in Sanfillipo B fibroblasts. J. Clin. Invest. 53: 85-90.

9. Neufeld, E. F., G. N. Sando, A. J. Garvin, and L. H. Rome. 1977. The transport of lysosomal enzymes. J. Supramol. Struct. (Suppl.). In press.

10. Hickman, S., and E. F. Neufeld. 1972. A hypothesis for I-cell disease: defective hydrolases that do not enter lysosomes. Biochem. Biophys. Res. Commun. 49: 992999.

11. Grebner, E. E., and I. Parish. 1974. An affinity adsorbent for $\mathrm{N}$-acetyl- $\beta$-D-hexosaminidase A. Biochem. Biophys. Acta. 350: 37-41.

12. Miller, A. L., R. G. Forst, and J. S. O'Brien. 1976. Purification of human liver $\beta$-D-galactosidases using affinity chromatography. Anal. Biochem. 74: 537-545.

13. Glaser, J. H., and W. S. Sly. 1973. $\beta$-Glucuronidase 
deficiency mucopolysaccharidosis: methods for enzymatic diagnosis. J. Lab. Clin. Med. 82: 969-977.

14. Lowry, O. H., N. J. Rosebrough, A. L. Farr, and R. J. Randall. 1951. Protein measurement with the Folin phenol reagent. J. Biol. Chem. 193: 265-275.

15. Hickman, S., L. J. Shapiro, and E. F. Neufeld. 1974. A recognition marker required for uptake of a lysosomal enzyme by cultured fibroblasts. Biochem. Biophys. Res. Commun. 57: 55-61.

16. Ballou, C. E., and W. C. Raschke. 1974. Polymorphism of the somatic antigen of yeast. Science (Wash. D. C.). 184: $127-134$.

17. Davis, L. G., J. I. Javaid, and E. G. Brunngraber. 1976. Identification of phosphoglycoproteins obtained from rat brain. FEBS (Fed. Eur. Biochem. Soc.) Lett. 65: 30-34.

18. Davis, L. G., A. J. R. Costello, J. I. Javaid, and E. B. Brunngraber. 1976. ${ }^{31} \mathrm{P}$ Nuclear magnetic resonance studies on the phosphoglycopeptides obtained from rat brain glycoprotein. FEBS (Fed. Eur. Biochem. Soc.) Lett. 65: $35-38$. 